\title{
Assessment of the prevalence of musculoskeletal ailments among musicians
}

\author{
Rafał Panasiuk ${ }^{1}$ \\ ${ }^{1}$ Department of International Cooperation, Polish Chamber of Physiotherapists, Poland \\ Correspondence to: Rafał Panasiuk, email: r.panasiuk@onet.pl \\ DOI: https://doi.org/10.5114/phr.2021.111812
}

Received: 09.04.2021 Reviewed: 10.04.2021 Accepted: 19.04.2021

\begin{abstract}
Background: A limited number of sources provided in Polish focused on people playing musical instruments and various ailments resulting from the play, giving the impression that this group of people should enjoy good health. Unfortunately, the analyzes of the conducted research indicate something else. Musicians are part of a society whose work is often invisible. In addition to concerts, weddings and special events, they spend much time locked in a recording studio, and the occurrence of an injury that excludes them from regular work may have social and psychological effects.
\end{abstract}

Aims: This study aimed to evaluate and analyze the frequency of musculoskeletal disorders among musicians.

Material and methods: The granting was carried out by the method of a diagnostic survey using a proprietary online questionnaire made available to the study group, broken down by sex, age and experience.

Results: The presented study shows the state of knowledge and awareness in a given professional group and, at the same time, shows how widespread and frequent the given problem is. In the study group, musicians report pain problems in as many as $95 \%$ of cases.

Conclusion: The musicians belong to the group of people particularly exposed to pain from the musculoskeletal system

Key words

pain, musculoskeletal disorders, musicians, instrumentalists. 


\section{Introduction}

Musculoskeletal disorders are a broad topic. They usually have a solid connection to lifestyle, work and leisure activities. The most common cause of musculoskeletal disorders is overload affecting the back, especially the lower back, the neck and shoulders, and upper and lower limbs. It involves impairment of certain motor functions of the body, which are the responsibility of muscles, joints and bones. According to the European Agency for Safety and Health at Work (EU-OSHA) [1], almost a quarter of people working in the $\mathrm{Eu}^{-}$ ropean Union have reported back problems, and over $22 \%$ have reported muscular problems. According to the Social Insurance Institution (ZUS), in Poland, $18 \%$ of those reporting inability to work are related to the musculoskeletal system [2].

In addition to the impact on the individual, musculoskeletal problems impact society - for the employer, it is the extra cost of paying health benefits, for the family the need for extra care [3].

The literature lists three main fundamental reasons for musculoskeletal injuries: the monotony of fast movements with low force but the high amplitude of repetition, the permanent load on the muscles caused by poor posture: leaning, twisting, stretching the hands for instruments or long hours of work in a sitting position, disproportionately large contraction with a larger amplitude than the others caused by for instance a characteristic movement of the instrument player or emotions during the play [4]. The most common problems among musicians are cervical and lumbar ailments [5].

A typical symptom of trauma is pain, described as a sensory experience, a kind of bodily response to protect tissues from damage [6]. So-called muscle stiffness is another symptom; however, it does not necessarily indicate a pathological condition [7]. The third most common symptom of musculoskeletal ailments is paresthesia, which is tingling or a numb sensation. Tingling paresthesia often accompanies diabetic neuropathy or traumatic nerve injury, but little is known abo- ut the molecular mechanisms underlying this enigmatic sensation [8].

In the music profession, the factor that initiates the whole pathological process leading to changes in individual anatomical systems in musicians is usually fatigue of tissues, disruption of their functions, and, consequently, compensation leading to the perpetuation of the resulting abnormalities. However, a direct correlation between long-term instrument playing and, for example, hand joint degeneration has not been yet established [9-11]. Neuropathy of the ulnar nerve, resulting from repeated flexion and extension of the elbow joint while playing an instrument, can be a major problem [12]. A recent study found that $58 \%$ of musicians have experienced cervical spine pain in the past year that prevents them from playing. Additionally, it was indicated that an average of $29 \%$ of the participants had to give up performing due to upper limb or back ailments [12].

\section{Aims}

The main objective of this study was to evaluate the frequency of particular musculoskeletal disorders among musicians. The following research questions were posted: Whether and how often music performers experience musculoskeletal pain? What factors are the primary sources of ailments for musicians? In which parts of the body do musicians most commonly experience pain? How do musicians try to deal with pain issues?

\section{Material and methods}

The survey was conducted on a sample of 135 musicians, 109 men, representing $80.7 \%$ of the respondents, and 26 women, representing 19.3\% of the participants. Almost $70 \%$ of the respondents were between 18 and 27 years old, 22\% between 28 and 37 years old, and the rest were older.

A diagnostic survey was conducted using an online survey created using a Google form. The survey questionnaire consisted of 20 questions, 
some of which were open-ended. Anyone associated with music, especially music-making and live music performance, was invited to participate in the study. Participation in the study was anonymous and voluntary.

\section{Results}

As many as $95 \%$, or 128 people, experienced pain while performing live music, and the source of the discomfort was the musical instrument they were using (Figure 1).
Regarding the symptoms' location, the respondents most often pointed to the hands as the source of the ailments: 83 (31.80\%). Slightly less frequently because 70 (26.82\%) respondents identified the spine as the cause of pain. The third most often indicated pain area was the shoulder complex, reported by 41 subjects (15.71\%), closely followed by the legs as a source of pain, 37 subjects (14.18\%). At the end of the ranking was the neck with 30 responses, which accounted for $11.49 \%$. The results are presented in Figure 2.

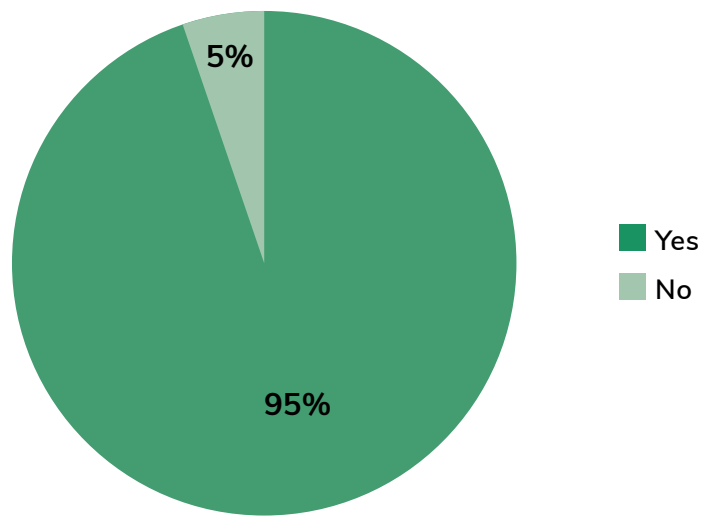

Figure 1. Distribution of answers given by surveyed musicians about pain and discomfort sensations while playing an instrument.

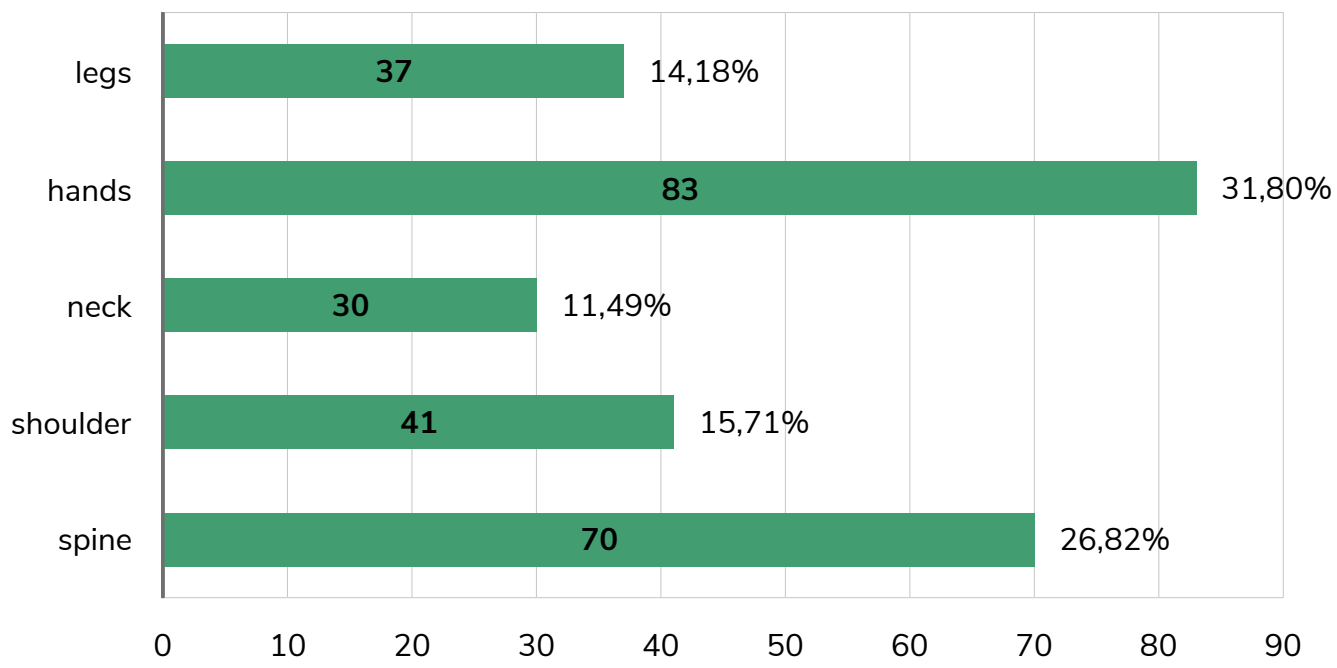

Figure 2. Areas of the body in which the musicians surveyed felt the most discomfort while playing the instrument. 
Figure 3 presents ways to manage pain problems. In most cases $(\mathrm{n}=69)$, the problem went away on its own, without any intervention or use of treatments or pharmacology. Also, 33\% of respondents $(\mathrm{n}=53)$ ignored the problem. Only 16 people chose to receive physiotherapy treatments. Also, $7 \%$ of respondents got advised about using pain medications and warming ointments.

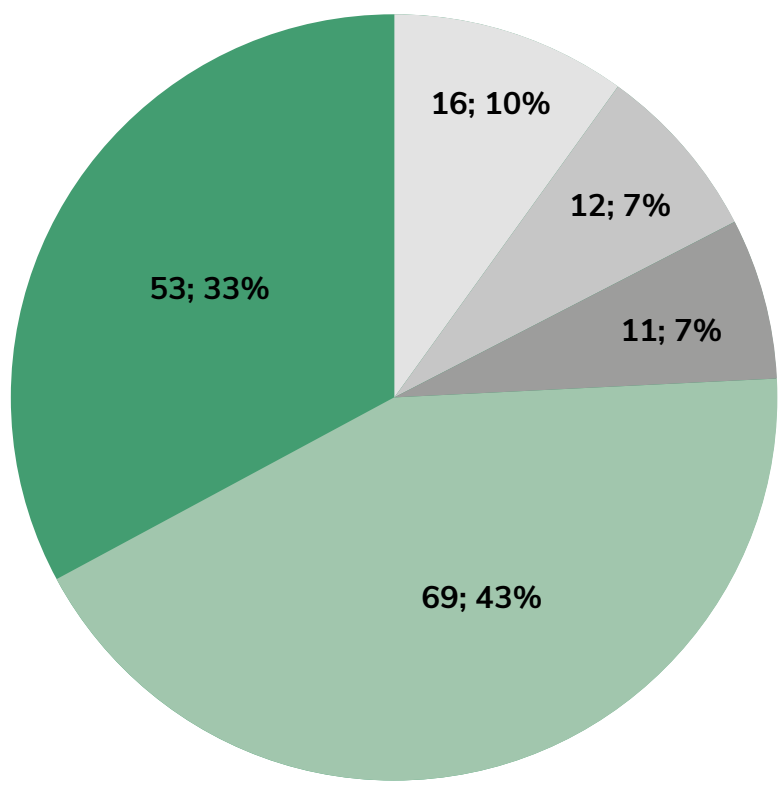

physiotherapy treatments

heating or cooling ointments

painkillers

problem has gone

ignoring the problem

Figure 3. Distribution of answers given by surveyed musicians about ways to cope with ailments.

Figure 4 shows numerically the numbers of subjects experiencing pain in the following instrument categories.

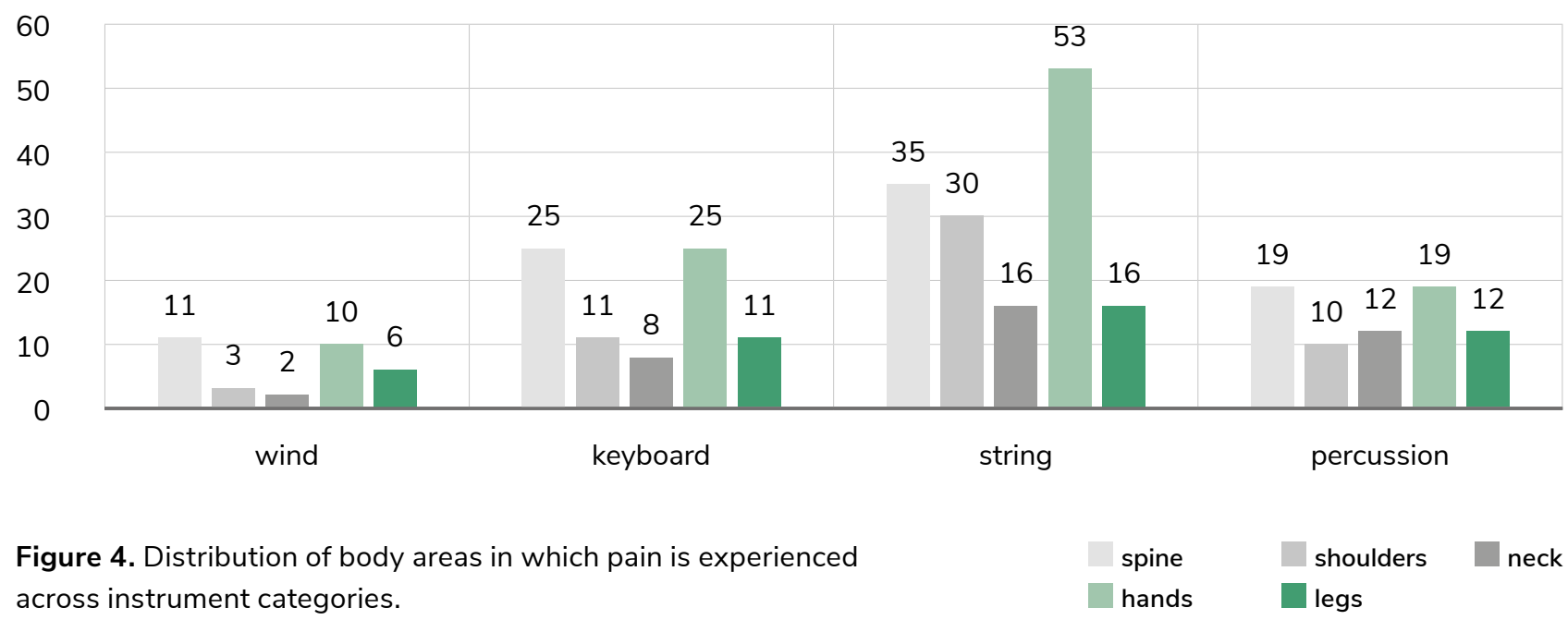




\section{Discussion}

According to the study, individual musculoskeletal ailments are a common phenomenon among young musicians. The vast majority of the respondents confirmed the occurrence of the ailment with particular emphasis on the place and frequency, pointing to the various elements of the human body that are exposed to pain and provoke its occurrence. Similar observations appear in the literature examining the health of musicians who play in professional orchestras [13].

According to our study, hands appeared to be the most frequently exposed to pain. This is because it is the part of the body that is most often used to play an instrument. Depending on the chosen work tool, the musician's hands, wrists, elbows or shoulders are particularly stressed by holding positions for many hours that do not occur in everyday life - they are almost non-anatomical. Depending on the playing technique and whether the musician uses the hand or an indirect object to produce sound, attention should be paid to wrist injuries, carpal tunnel syndrome, or ligament fatigue. The second most common area of discomfort is the spine, and like the hands, it is stressed by special (forced) positions. Often the wrong position is due to a lack of knowledge of the ergonomics of the musician's work or due to fashion, as in the case of punk bands when low-slung guitars are a kind of behaviour for character creation. Other areas of pain indicated by respondents may be due to individual health issues. Despite the frequency of the symptoms, the vast majority of them were temporary, meaning that the genesis of the symptoms originated from playing the instrument. It is important to note that many minor problems can lead over time to the appearance of dangerous, neuropathic symptoms. Ulnar nerve ailments in musicians have long been known and often discussed in the literature [14-17].

Alarming is the fact that the participants tend to ignore overload symptoms and related ailments. This may be due to poor medical education and lack of awareness and consequences of damage to specific musculoskeletal systems. Using non-steroidal anti-inflammatory drugs (NSAIDs) as a panacea for all symptoms can be dangerous. It is encouraging that at least one in ten of those surveyed decided to use the services of a physiotherapist; this allows them to check the cause and eliminate ailments resulting from overloading the musculoskeletal system.

Misalignment of the work tool is a common cause provoking pain due to excessive bending, sitting in a hunched position or other odd, unnatural positions. It is hard to talk about re-education being the solution to the problem in such cases. Many musicians consider a given position to be natural or even necessary for playing/working, and a suggestion to change is often met with negation and ignorance.

For drummers, changing wooden sticks or brooms forces a different grip on the player. The tool, as mentioned above, differs in dimension, weight, the material it is made of and the coating. As a result, it is an extremely variable element during the play, and its different use can disrupt the developed movement patterns and coordination; and at the same time, despite the similar shape, it can limit the ergonomics of the play. The same is true for guitarists who use so-called "picks" - plastic pieces that help produce a more aggressive sound than tugging with the fingers. Here the variety of shapes, sizes and materials, including plastic, metal, leather or even stone, affects the grip and positioning of the wrist. The analogy also applies to violin and bow.

An important and often overlooked aspect, despite being known for many years and belonging to the work of the musician, is insufficient or overlooked muscle warm-up. However, it is important to ensure that the body temperature is raised and muscles are stretched, just as in sports, warm-up exercises should be done to avoid injury or pain. An additional advantage is that well-executed warm-up influences the fluidity of the movements performed, thus simultaneously improving the quality of the performance [18]. 


\section{Conclusion}

Musicians are particularly vulnerable to musculoskeletal pain, with up to $95 \%$ of musicians reporting these problems. The most common areas of pain are the hands and the spine. Unfortunately, problems and ailments are most often ignored, and only at a later stage are actions taken to treat them. Despite the ailments of pain that accompany playing a musical instrument, only $4 \%$ of the cases were severe enough to cause individuals to quit playing instruments.

\section{References}

1. European Agency for Safety and Health at Work, EU-OSHA. Introduction to work-related musculoskeletal disorders. European Union 2007. FACTS 71/2007. https://osha.europa.eu/en/publications/ factsheet-71-introduction-work-related-musculoskeletal-disorders (access: 02.12.2021).

2. Ciecieląg P, Lednicki B, Moskalewicz J, et al. Ocena zdrowia ludności Polski w 2004 roku. Statistics Poland, Warsaw: 2006.

3. European Foundation for the Improvement of $\mathrm{Li}^{-}$ ving and Working Conditions (Eurofound): The fourth working conditions survey, European Union 2015. https://www.eurofound.europa.eu/pl/publications/report/2007/working-conditions/fourth-european-working-conditions-survey (access: 02.12.2021).

4. Evans P. Repeat performance. Occup Safety Health. 1992;(8):12-4.

5. Jankowicz-Szymaoska, A, Pałucka, M, Mikołajczyk E. Quality of body posture in fi rst and six grade students of musical primary school. Fizjoterapia. 2009;17(1) 20-9.

6. Wordliczek J, Dobrogowski J. Leczenie bólu. Wydawnictwo PZWL, Warszawa: 2017.

7. Kuszewski M. Ocena skuteczności niektórych technik rozciągających w obrębie kończyn dolnych w świetle wybranych testów. Rozprawa doktorska, AWF, Katowice: 2005.

8. Ochoa JL, Torebjörk HE. Paraesthesiae from ectopic impulse generation in human sensory nerves. Brain. 1980;103(4):835-53.

9. Hansen PA, Reed K. Common musculoskeletal problems in the performing artist. Phys Med Rehabil Clin N Am. 2006;17(4):789-801
10. Bird HA, Wright V. Traumatic synovitis in a classical guitarist: a study of joint laxity. Ann Rheum Dis. 1981;40(2):161-3.

11. Wilson RJ, Watson JT, Lee DH. Nerve entrapment syndromes in musicians. Clin Anat. 2014;27(6):861865.

12. Szczechowicz J, Kania M. Pain of the spine and upper limbs in double bass players. Health Prom Phys Act. 2019;4(9):27-39.

13. Berque P, Gray H, McFadyen A. Playing-Related Musculoskeletal Problems Among Professional Orchestra Musicians in Scotland: A Prevalence Study Using a Validated Instrument, the Musculoskeletal Pain Intensity and Interference Questionnaire for Musicians (MPIIQM). Med Probl Perform Art. 2016;31(2):78-86.

14. Lambert CM. Hand and upper limb problems of instrumental musicians. $\mathrm{Br} \mathrm{J}$ Rheumatol. 1992;31(4):265-271.

15. Lederman RJ. Nerve entrapment syndromes in instrumental musicians. Med Probl Perform Art. 1986;1(2):45-8.

16. Nawrot P, Nowakowski A, Łabaziewicz L. Chirurgiczne leczenie neuropatii uciskowych kończyny górnej. Wydawnictwo Folium, Lublin: 2003.

17. Nakano KK. Peripheral nerve entrapments, repetitive strain disorder, occupation-related syndromes, bursitis, and tendonitis. Curr Opin Rheumatol. 1991;3(2):226-39.

18. Janiszewski M. Ergonomia zawodu muzyka: analiza obciążeń i przeciążeń zawodowych muzyków. Wydawnictwo Naukowe PWN, Warsaw: 1992. 